\title{
EVALUASI PROGRAM PEMBELAJARAN GURU MATA PELAJARAN EKONOMI SEKOLAH MENENGAH ATAS (SMA) NEGERI DAN SWASTA DI KABUPATEN TULUNGAGUNG
}

\author{
Hendro Dwi Baskoro ${ }^{1}$, Hari Wahyono ${ }^{2}$, Nasikh $^{3}$ \\ 1. Economic Education Program, Faculty of Economics, State University Malang \\ 2. Economic Education Program, Faculty of Economics, State University Malang \\ endrewbas@gmail.com, hari.wahyono.fe@um.ac.id nasikh.fe@um.ac.id
}

\begin{abstract}
The purpose of this research is (1) to know the quality of learning device of economic teacher learning in Public High School and Private at Tulungagung Regency; (2) to know the quality of the implementation of economics teacher learning in Public High School and Private at Tulungagung Regency; (3) to know the quality of evaluation of economic teacher learning in Public High School and Private at Tulungagung Regency. This research uses evaluation approach. Research data in the form of exposure of resource persons from Senior High School 1 Kedungwaru and Senior High School PGRI Kalangbret in Tulungagung Regency. Data collection is done by interview, observation and documentation. Analysis of data used is data collection and take conclusions. While checking the validity of data findings is done by extension of participation, trianggulasi and diligence of observation.
\end{abstract}

Key Word: Evaluation, Learning Program, Economic Teacher

\section{History of Article:}

Received : (9 Agustus 2017), Accepted $:(19$ September 2017), Publised : (15 Oktober 2017)

\section{Citation (Example):}

Baskoro, Hendro Dwi, Hari Wahyono, Nasikh (2017) Evaluasi Program Pembelajaran Guru Mata Pelajaran Ekonomi Sekolah Menengah Atas (SMA) Negeri Dan Swasta Di Kabupaten Tulungagung [Evaluation of Teachers Economic Learning Program of Public Senior High School (SMA) Negeri dan Private In Tulungagung District], 10(2), 104-110.

(C) Universitas Negeri Malang 


\section{PENDAHULUAN}

Perkembangan ilmu pengetahuan dan teknologi yang kian cepat, mendorong manusia untuk selalu meningkatkan mutu kualitas pendidikannya sehingga mampu bersaing di era globalisasi. Guru merupakan komponen paling menentukan dalam sistem pendidikan secara keseluruhan yang harus mendapatkan perhatian sentral, pertama dan utama. Tuntutan zaman mengharuskan guru terus meningkatkan kualitasnya dalam melaksanakan tugas profesio- nalitasnya sebagai guru.

Guru merupakan komponen paling menentukan dalam system pendidikan secara keseluruhan yang harus mendapatkan perhatian sentral, pertama dan utama. Figur yang satu ini akan senantiasa menjadi sorotan yang strategis ketika berbicara masalah pendidikan, karena guru selalu terkait dengan komponen manapun dalam sistem pendidikan. Menurut Atmosudirjo (dalam Yamin dan Maisah, 2010: p. 26) disebutkan bahwa guru memiliki peranan yang sangat besar dalam pendidikan, di pundaknya dibebani suatu tanggung jawab atas mutu pendidikan. Berdasarkan Undang-Undang No.14 tahun 2005 tentang Guru dan Dosen, guru adalah pendidik profesional dengan tugas utama mendidik, mengajar, membimbing, mengarah- kan, melatih, menilai, dan mengevaluasi peserta didik pada pendidikan anak usia dini jalur pendidikan formal, pendidikan dasar, dan pendidikan menengah.

Tuntutan zaman mengharuskan guru terus meningkatkan kualitasnya dalam melaksanakan tugas profesionalitasnya sebagai guru.Sehingga, Posisi strategis guru untuk meningkatkan mutu hasil pendidikan sangat dipengaruhi oleh kemampuan profesional guru dan mutu kerjanya. Kompetensi profesional dipandang sebagai elemen kunci untuk guru karena guru professional tahu apa yang mereka harus seperti apa dan pengajaran harus sekitar. Oleh karena itu upaya yang dilakukan untuk meningkatkan kualitas pendidikan tidak akan memberikan sumbangan yang signifikan tanpa di dukung oleh guru yang professional dan berkualitas. Menurut Surya dalam Kunandar (2007:p. 47), guru yang profesional akan tercermin dalam pelaksanaan pengabdian tugas-tugas yang ditandai dengan keahlian baik dalam materi maupun metode. Selain itu juga ditunjukkan melalui tanggung jawabnya dalam melaksanakan seluruh pengabdiannya.

Evaluasi diperlukan untuk menilai efektifitas program pembelajaran yang sudah dibuat oleh seorang guru yang meliputi perencanaan pembelajaran seperti program tahunan (prota), program semester (promes), silabus dan RPP, kemudian pelaksanaan pembelajaran dan evaluasi pembelajaran. Kemudian komponenkomponen tersebut dianalisis lalu diberi penilaian dari analisis tersebut. Data dari hasil evaluasi perangkat pembelajaran yang benar, lengkap dan akurat dapat dijadikan sebagai dasar pertimbangan dan penilaian. Hal tersebut sesuai dengan

Evaluasi ini akan menentukan apakah perangkat pembelajaran sudah sesuai dengan pelaksanaan di kelas atau belum. Oleh karena itu kemampuan guru yang kompeten merupakan sebuah keharusan yang dijadikan pedoman oleh guru untuk menjadi lebih baik.

\section{METODE PENELITIAN}

Berdasarkan judul, rumusan masalah dan tujuan seperti yang telah dipaparkan, maka penelitian ini didesain sebagai penelitian evaluasi (evaluation research) dengan menggunakan countenance evaluation model yang dikemukakan oleh Stake. Penelitian evaluasi dengan menggunakan Model Countenance Stake, 
yang meliputi evaluasi Antecedents, Transactions, dan Outputs (Worthen \& Sanders, 1973: p.121)

Objek evaluasi adalah program pendidilan ekonomi di Sekolah Menengah Atas (SMA) Negeri dan Swasta di Kabupaten Tulungagung. Evaluasi pada prinsipnya diarahkan untuk menentukan nilai sesuatu, bisa berupa program, produk, prosedur, tujuan, atau manfaat potensial dari pendekatan yang telah dirancang untuk tujuan tertentu.Maka dari itu, rancangan penelitian diarahkan untuk menggali data guna memperoleh informasi yang diperlukan untuk menentukan nilai atau kebermaknaan objek yang dievaluasi, yaitu program pendidikan ekonomi di SMA.

Dimana penelitian evaluatif adalah penelitian yang bertujuan membandingkan sebuah gejala di lapangan secara menyeluruh dan sesuai dengan konteks melalui pengumpulan data dengan progam yang telah ditentukan oleh peneliti. Menurut Sukmadinata (2010: p. 120) "penelitian evaluatif yaitu suatu desain dan prosedur evaluasi dalam mengumpulkan dan menganalisis data secara sistematik untuk menentukan nilai atau manfaat (worth) dari suatu praktik (pendidikan)". Secara umum tujuan dari penelitian evaluatif adalah untuk merancang, menyempurnakan, dan menguji pelaksanaan suatu praktek pendidikan.

\section{HASIL DAN PEMBAHASAN}

\section{Kualitas Perangkat Pembelajaran}

Kualitas masing-masing perangkat pembelajaran antara guru ekonomi Sekolah Menengah Atas di kabupaten Tulungagung antara yang satu dengan yang lainnya berbeda-beda. Penulis meneliti perangkat pembelajaran yang terdiri dari Program Tahunan (Prota), Program Semester (Promes), SILABUS, dan Rancangan Pelaksanaan Pembelajaran (RPP). Berdasarkan hasil penelitian, penulis membandingkan kualitas perangkat pembelajaran antara guru ekonomi SMAN 1 Kedungwaru dan SMA PGRI Kalangbret dengan standar saat ini yang tentunya sesuai dengan kurikulum 2013. Jadi sesuai dengan pemaparan dan temuan penelitian pada bab III diperoleh bahwa kemampuan guru ekonomi dalam penyusunan Program Tahunan Sekolah Menengah Atas Negeri dan Swasta di kabupaten Tulungagung yaitu yang pertama guru ekonomi SMAN 1 Kedungwaru (SS) yaitu $100 \%$ persen berklasifikasi sangat baik dan guru ekonomi SMA PGRI Kalangbret (AT) yaitu 83 persen berklasifikasi baik. Telaah untuk mengetahui kemampuan guru ekonomi pada penelitian ini dalam menyusun program tahunan antara lain aspek yang pertama ketepatan SK dan KD dengan deskriptor rumusan Standar Kompetensi (SK) sesuai dengan standar isi, rumusan Kompetensi Dasar (KD) sesuai dengan standar isi, aspek yang kedua keakuratan materi pembelajaran dengan deskriptor materi pembelajaran benar secara teoritis, materi pembelajaran mendukung pencapaian KD (Selaras dengan KD), aspek yang ketiga alokasi waktu dengan deskriptor alokasi waktu sesuai dengan cakupan kompetensi, alokasi waktu sesuai dengan kalender pendidikan yang telah disusun (Sapir \& Hardinto, 2009: p. 25)

Pada Program tahunan bisa dibuat dalam bentuk tabel yang berisi deskripsi tentang Standar Kom- petensi (SK), Kompetensi Dasar (KD), Materi Pokok, alokasi waktu, dan kolom keterangan (Sapir \& Hardinto, 2009: p. 34). Dari penjelasan di atas dapat disimpulkan bahwa kualitas penyusunan program tahunan guru ekonomi dari SMAN 1 Kedungwaru lebih baik dari SMA PGRI Kalangbret.

Kemampuan guru ekonomi dalam penyusunan Program Semester Sekolah Menengah Atas di kabupaten Tulungagung yaitu yang pertama guru ekonomi 
SMAN 1 Kedungwaru (SS) yaitu 100 persen berklasifikasi sangat baik dan guru ekonom SMA PGRI Kalangbret (AT) yaitu 83 persen berklasifikasi baik. Menurut Sapir \& Hardinto (2009) program semester disusun dalam bentuk/format tabel: berisi deskripsi tentang identitas (nama sekolah, mata pelajaran, kelas, semester, tahun ajaran, jumlah pekan efektif, jam efektif cadangan), kolom pertama deskripsi tentang SK, KD, Materi Pokok; kolom kedua alokasi waktu meliputi waktu tatap muka, ulangan harian, ujian tengah semester, ujian akhir semester, dan waktu cadangan; kolom ketiga memuat nama bulan, untuk semester gasal dimulai dari bulan Juli sampai bulan Desember, sedangkan untuk semester genap dimulai dari bulan Januari sampai bulan Juli, masing- masing kolom bulan dibagi menjadi empat/ lima kolom, sedangkan dalam satu tahun ajaran dimulai dari bulan Januari hingga Desember. Dari penjelasan di atas dapat disimpulkan bahwa kualitas penyusunan program semester guru ekonomi SMAN 1 Kedungwaru lebih baik dari SMA PGRI Kalangbret.

Kemampuan guru ekonomi dalam penyusunan SILABUS Sekolah Menengah Atas di kabu paten Tulungagung yaitu guru ekonomi SMAN 1 Kedungwaru (SS) dan guru ekonomi SMA PGRI Kalangbret (AT) sama, karena ada SILABUS yang dikembangkan oleh Dinas Pendidikan berdasarkan Standar Isi (SI) dan Standar Kompetensi Kelulusan (SKL) serta panduan kurikulum 2013 yang menjadi acuan guru dalam pelaksanaan pembelajaran.

Kemudian kemampuan guru ekonomi dalam penyusunan Rancangan Pelaksanaan Pembe-lajaran (RPP) Sekolah Menengah Atas di kabupaten Tulungagung yaitu yang pertama guru ekonomi SMAN 1 Kedungwaru (SS) yaitu 90 persen berklasifikasi baik dan guru ekonomi SMA PGRI Kalangbret (AT) yaitu 82,5 persen berklasifikasi baik.

\section{Kualitas Pelaksanaan Pembelajaran}

Berdasarkan hasil perhitungan kemampuan guru ekonomi Sekolah Menengah Atas di Kabupaten Tulungagung yang pertama dari guru ekonomi SMAN 1 Kedungwaru (SS) dalam proses pembelajaran yaitu 83 persen berklasifikasi baik dan guru ekonomi SMA PGRI Kalangbret (AT) mendapatkan 78 persen berklasifikasi baik.

Dalam pelaksanaan pembelajaran terdiri dari tiga tahap, yaitu: (a) tahap pendahuluan, (b) tahap inti, (c) penutup. Tahap pendahuluan terdiri dari apersepsi dan pemberian motivasi. Pada tahap inti, mencakup penyampaian materi serta pelaksanaan pembelajaran sesuai dengan metode yang digunakan. Aspek-aspek yang digunakan penulis untuk menelaah kemampuan guru dalam pelaksanaan mengajar dikelas yaitu pertama aspek penilaian membuka pelajaran yang mempunyai dua indikator. Indikator yang pertama adalah motivasi dengan deskriptor menyiapkan siswa mengikuti pembelajaran melalui kegiatan yang menarik perhatian siswa dan indikator kedua yaitu dengan mengaitkan peran/manfaat penguasaan kompetensi dalam kehidupan siswa.

Aspek yang kedua melaksanakan kegiatan inti dengan beberapa indikator, indikator yang pertama menggunakan metode yang teridiri dari beberapa deskriptor yaitu metode yang digunakan melibatkan siswa untuk aktif melakukan tahapan aktivitas pembelajaran sesuai dengan kompetensi yang akan dicapai, penggunaan metode melibatkan siswa untuk bekerja sama dengan siswa lain (learning community), metode yang digunakan melibatkan siswa untuk mengeksplorasi serta memperluas pemahaman kompetensi dan menciptakan suasana kelas yang kondusif dan menyenangkan. Indikator yang kedua ketepatan 
materi deskriptornya, yaitu materi yang disajikan sesuai dan menunjang pencapaian kompetensi dasar dan ketepatan materi yang disajikan benar secara teoritis, materi pokok dijabarkan/ dikembangkan dari indikator secara memadai. Indikator yang ketiga melaksanakan kegiatan inti yaitu penguasaan kompetensi deskriptornya guru menguasai dan dapat mendemontrasikan kompetensi yang harus dikuasai siswa melalui sebuah contoh, guru memberikan balikan dan model secara jelas terhadap performansi siswa dan guru dapat merespon pertanyaan, pendapat dan komentar siswa secara tepat dan memadai. Indikator yang keempat yaitu penggunaan media pembelajaran yang terdiri dari tiga indikator, indikator pertama menggunakan media pembelajaran yang sesuai dengan pembelajaran, memanfaatkan media secara efektif dan efisien, serta memanfaatkan media dengan melibatkan siswa agar aktif dalam proses pembelajaran.

Aspek penilaian yang ketiga pada kemampuan guru dalam pelaksanaan mengajar dikelas yaitu menutup proses pembelajaran dengan melakukan refleksi dan penilaian, deskriptornya yaitu mendorong siswa untuk membuat kesimpulan dari apa yang sudah dipelajari penilaian dan refleksi, deskriptornya antara lain guru mendorong siswa mengungkapkan kesulitan yang dihadapi siswa, membantu siswa untuk menyim- pulkan apa yang telah dipelajari dalam proses pembelajaran, dan melakukan penilaian dengan instrument yang sesuai dengan KD.

Aspek yang terakhir yaitu faktor penunjang dengan indikator penggunaan bahasa yang jelas serta mudah dipahami (komunikatif) oleh siswa, pengaturan waktu, rasa percaya diri, dan penampilan dengan deskriptor penggunaan bahasa jelas dan mudah dipahami (komunikatif), gerak tubuh dan tatapan menunjukkan sikap yang tenang dan percaya diri, pengorganisasian waktu tepat sesuai dengan perencanaan, berbusana dan berdandan sopan, sederhana, dan rapi, sikap santun serta adil dan menghargai semua siswa.

Jadi berdasarkan hasil penelitian maka dapat disimpulkan bahwa kemampuan guru ekonomi dalam pelaksanaan pembelajaran dari SMAN 1 Kedungwaru (SS) lebih baik daripada guru ekonomi dari SMA PGRI Kalangbret (AT). Karena pada saat melaksanakan kegiatan inti, guru masih kurang dalam menggunakan berbagai media yang sesuai dengan kompetensi.

\section{Kesesuaian Perangakat Pembelajaran dengan Pembelajaran Scientific}

Pembelajaran dengan pendekatan scientific adalah pem- belajaran yang terdiri atas kegiatan mengamati (untuk mengidentifikasi hal-hal yang ingin diketahui), merumuskan pertanyaan (dan merumuskan hipotesis), mencoba/ mengumpulkan data (informasi) dengan berbagai teknik, mengasosiasi/ mengolah data (informasi) dan menarik kesimpulan serta mengkomunikasikan hasil yang terdiri dari kesimpulan untuk memperoleh pengetahuan, ketram- pilan dan sikap.

Dari hasil pengamatan penulis, baik perangkat pembelajaran guru ekonomi SMAN 1 Kedungwaru dan guru ekonomi SMA PGRI Kalangbret semuanya sudah mengandung pembelajaran scientific terbukti dari paparan data di bab III dari SMAN 1 Kedungwaru dan SMA PGRI Kalangbret keduanya mendapat $100 \%$ berklasifikasi sangat baik untuk kesesuaian perangkat pembelajaran dengan pembelajaran scientific. Dalam perangkat pembelajaran dari SMA 1 Kedungwaaru dan SMA PGRI Kalangbret sudah termuat komponen-komponen pembelajaran scientific. Namun dalam pelak- sanaanya guru tidak selalu bisa mencantumkan pembelajaran scientific dalam proses pembelajaran. Menurut guru 
ekonomi dari SMAN 1 Kedungwaru dan SMA PGRI Kalangbret, pembelajaran scientific memang bagus diaplikasikan kepada siswa dalam proses pembelajaran, namun pada kenyataanya tidak semua materi bisa dikaitkan dengan pembelajaran scientific, sehingga guru selalu menyesuaikan materi yang akan diajarkan dengan dikaitkan dengan pembelajaran scientific sehingga proses pembelajaran bisa berjalan dengan baik.

\section{Kesesuaian Antara Perangkat Pembelajaran dan Pelaksananan Pembelajaran}

Berdasarkan hasil penelitian yang dilakukan oleh penulis pada saat melakukan penelitian di dalam kelas dan hasil wawancara guru ekonomi Sekolah Menengah Atas di Kabupaten Tulungagung, yaitu dari guru ekonomi SMAN 1 Kedungwaru (SS) dan guru ekonomi SMA PGRI Kalangbret (AT), dihasilkan bahwa penyusunan perangkat pembelajaran yang dibuat oleh masing-masing guru dilakukan pada awal semester, tidak dilakukan pada setiap kali mengajar, setiap guru juga memiliki kualitas penyusunan perangkat pembelajaran dan kendala dalam penyusunan perangkat pembelajaran yang berbeda-beda.

Dari hasil wawancara yang dilakukan pada responden guru SMAN 1 Kedungwaru (SS) dan guru SMA PGRI Kalangbret (AT) serta pengamatan langsung yang dilakukan oleh penulis dengan mengukuti kegiatan belajar mengajar di dalam kelas. Dari penjelasan tersebut dapat disimpulkan bahwa terdapat faktor-faktor tertentu yang membuat ketidaksesuaian antara perangkat pembelajaran dengan pelaksanaan mengajar yang telah disusun oleh guru, diantaranya yaitu situasi yang ada di kelas dikarenakan siswanya kurang aktif dan kurang memahami materi dalam proses pembelajaran, sehingga materi yang diajarkan tidak bisa berjalan dengan maksimal, keadaan atau situasi yang mendadak pada saat guru mengajar ada kegiatan-kegiatan lain di sekolah yang mengganggu jam pelajaran di kelas, tetapi guru tetap berusaha untuk menyesuaikan antara perangkat pembelajaran yang telah disusun dengan pelaksanaan pembelajaran yang ada dikelas sehingga bisa berjalan sesuai perencanaan.

\section{KESIMPULAN}

Berdasarkan hasil penelitian dan pembahasan yang telah diuraikan maka dapat disimpulkan sebagai berikut: 1) Kualitas perangkat pembelajaran guru ekonomi dari SMAN 1 Kedungwaru lebih baik dari SMA PGRI Kalangbret dengan persentasi Rencana Pelaksanaan Pembelajaran (RPP) guru ekonomi SMAN 1 Kedungwaru yaitu 90\% persen dan guru ekonomi SMA PGRI Kalangbret yaitu $82,5 \%$ persen; 2) Kualitas pelaksanaan pembelajaran yang dilakukan oleh guru ekonomi dari SMAN 1 Kedungwaru lebih baik daripada guru dari SMA PGRI Kalangbret, dengan persentase guru ekonomi SMAN 1 Kedungwaru yaitu $83 \%$ persen dan guru ekonomi SMA PGRI Kalangbret yaitu 78\% persen; 3) Kesesuaian antara perangkat pembelajaran dan pelaksanaan pembelajaran yang telah dibuat setiap guru ekonomi sekolah menengah atas dari SMAN 1 Kedungwaru (SS) dan SMA PGRI Kalangbret (AT) setiap waktu mengajar tidak bisa selalu sesuai dengan rancangan pembelajaran yang telah dibuat.

Saran yang bisa peneliti rekomendasikan kepada para guru adalah guru diharapkan sebelum melaksanakan kegiatan pembelajaran menyusun perangkat pembelajaran serta meningkatkan kualitas dalam menyusun perangkat pembelajaran 
Program Tahunan, Program Semester, SILABUS, dan Rancangan Pelaksanaan Pembelajaran (RPP) sebelum pembelajaran sehingga perangkat pembelajaran bisa dijadikan acuan pelaksanaan pembelajaran untuk menjadi guru yang berkualitas.

\section{DAFTAR RUJUKAN}

Kunandar (2007) Evaluasi Profesional, Implementasi Kurikulum Tingkat satuan pendidikan (KTSP) dan Sukses dalam sertifikasi Guru. Jakarta: PT. Raja Garfindo Persada.

Sapir \& Hardinto, Prih (2009) Perencanaan Pembelajaran Ekonomi. Malang: Fakultas Ekonomi Universitas Negeri Malang

Sukmadinata, Syaodih Nana (2010) Metode Penelitian Pendidikan. Bandung: PT Remaja Rosdakarya

Undang-UndangRepublik Indonesia Nomor 14 Tahun 2005 tentang Guru dan Dosen. Jakarta: Sinar Garafika

Worthen, R. \& Sanders, J (1973) Educational evaluation theory and practice.California: Wardsworth Publishing Company.

Yamin, Martinis \& Maisah (2010) Standarisasi kinerja guru. Jakarta: Gaung Persada Press 